\title{
Do valor medico-legal da fossa navicular nos casos de defloração. (*)
}

Consignam os autores que de todos os signaes de virgindade o mais importante é a integridade da hymen.

Semelhante conceito não soffreria impuynação se não fossem os casos consignados tambem pelos mesmos autores de copula carnal com mulheres virgens até então, por-encontrar-se nellas cssa membrana inteira: são os casos de hymens complacentes, isto é, de membranas de orificio permeavel á qualquer corpo isomorpho ao membro viril em erecção, sem lacerarem-se. Esta circumstancia que não é tão rara como se suppõe, os proprios autores o dizem, e eu mesmo tenho observado, difficulta muitas vezes o diagnostico de defloração que, se no sentido anatomico importa a laceração dessa membrana, medico-legalmente considerada nem sempre se denuncia por essa lesão, e nem por isto o diagnostico deixa de se estabelecer. É justamente á estes casos que se deve prestar a mais es-

(*) Memoria escripta para o VI Congresso Brasileiro de Medicina e Cirurgia a realisar-se em S. Paulo na primeira quinzena do mez de Setembro de 1907. 


\section{$-6 \mathrm{I}-$}

crupulosa attenção, estudando tơdos os outros signaes de virgindade, porquanto, se a hymen é o mais importante, não é ella o unico.

De todos esses signaes accessorios, que deixo de mencionar por ocioso, não ha nenhum que nos casos de copula carnal com persistencia dessa membrana possa por si só, de prompto, resolver a duvida. Pois bem.

Cabe-me a satisfação, pois na casuistica medicolegal não se faz menção deste elemento de prova, da descoberta ou, melhor, indicação de um signal que para mim tem tanto valor quanto a hymen e que, nos casos de copula protrahida, por si só concorre para a lucidez do diagnostico: é a fossa navicular.

Faz, se bem me lembro i 8 a 20 annos que tive de examinar uma rapariga cuja exhuberancia das formas, de accordo com o que ella firmemente dizia, propugnava por sua virgindade. Seus orgãos gènitaes externos eram os de uma virgem. A hymen lá estava inteira, como trazendo inscripto o seguinte avisonemo me tetigit. -

Só depois de repetidos exames foi que meu olhar de investigador fixou-se na fossa navicular, cuja conformação, em uma virgem, estava de todo alterada. $\mathrm{E}$ como semelhante alteração podia dar-se quer em virtude de coito vestibular quer va'ginal, sendo a hymen complacente, ousei, secundum artem, tránspor, o orificio hymeneal, que com surpreza minha distendeu-se a ponto de me deixar perceber a vagina dilatada, as rugas de sua mucosa diminuidas, o que levou a paciente a confessar o facto: isto é, de longa data praticava a copula carnal. D'ahi em deante nunca mais deixei de examinar a fossa navicular e não cesso de proclamal-a como um signal de defloração em casos qual o acima citado ou referido, tão importante quanto 
a hymen. Eis ahi um bom criterio de julgamento, cujo valor não foi, a menos que eu saiba, considerado pelos autores.

Permittam-se-me algumas reflexões attinentes ao assumpto. A fossa navicular é limitada para deante pela furcula e para traz pela hymen: é como se fosse um infundibulum. Penetrando na vagina um corpo duro, isormopho ao membro viril em erecção, funccionando como no acto da copula, exerce elle sobre esse infundibulum tal ou qual pressão que, repetida, o vae alargando ou deprimindo, e portanto tornando-o raso ou menos profundo até quasi o seu desfazimento.

Imagine-se um angulo agudo cujo vertice dirigido para baixo e para traz confunde-se com o raphe perineal. A' medida que os lados deste angulo vão se alargando ou afastando, vae por sua vez tornando-se elle menos agudo, affectando a forma de um angulo obtuso: applique-se a comparação á este signal anatomico e eil-o trańsformado núm valioso criterio de. diagnostico de defloração que, no opinar do erudito professor SouzA Lima, é a copula com mulher virgem. $\mathrm{E}$ desde que o acto praticado uma ou mais vezes não implique sempre a ruptura da hymen, como é sabido, segue-se que em taes casos não representa essa membrana o valor que só em these se lhe tem conferido aos casos outros em que, representando o maior numero, é verdade, ella accusa pelas lesões apresentadas $o$ ataque que softreu.

O pranteado professor NiNA RodRIGUEs com o qual troquei idéas á respeito, mostrou-se de accordo commigo, considerando o assumpto muito interessante, promettendo tambem escrever no mesmo sentido, o que infelizmente não se realisou.

Considerando ou definindo a defloração como o fez o professor Souza Lima, a copula com mulher vir- 
gem, a perda dos signaes caracteristicos da virgindade deve constituir o elemento substancial do delicto ou, como se diz na gyria juridica, a prova provada. E como a copula pode effectuar-se independentemente da ruptura ou laceração da hymen, devido á sua particular estructura histologica, a perda desses signaes poderia escapar á um espirito desprevenido, se não fosse o subsidio que ao caso prestasse o exame da fossa navicular; não falando no erro contrario proveniente de uma falsa interpretação applicada a divisões e chanfraduras congenitas, mais ou menos profundas da membrana nos casos de hymens irregulares, atypicas.

Muito de industria escrevi estructura histologica porquanto, já o tendo feito uma vez, houve quem reparasse nessa redundancia ou supposto erro.

Mas, quando assim me enunciei foi justamente parạ significar uma condição particularissima da membrana, expressão esta adoptada e empregada com toda procedencia por CASPER, quando a proposito do estudo da putrefacção dizendo que os orgãos internos não soffrem-na no mesmo momento nem no mesmo gráu, escreveu sua estructura histologica differente

E aproveitando esta opportunidade não posso silenciar sobre o que se lê na obra de Strassman, a pag. I 34 a proposito da resistencia relativamente consideravel que apresenta a hymen á putrefacção.

Alli se escreveu, entre outras cousas, que Grigorescu verificou a integridade da hymen e poude portanto demonstrar que não se havia dado a suspeitada deflorafão em uma menina exhumada um anno depois da morte

E', de facto, curioso o que acabei de transcrever. Quem conhece a natureza diversa dessa membrana, sua 


\section{$-64-$}

estructura histologica desde a delgadeza comparavel a uma pellicula de cebola até a sua dureza coriacea, não póde acceitar nos termos em que foi enunciado, semelhante conceito. Quando muito, só em casos devéras especiaes essa resistencia podia dar-se, tratando-se de membrana partilhando dessa natureza coriacea ou mesmo calcificada, como affirmam alguns: nos outros casos não é explicavel que ella resista por tanto tempo, um anno, ao processo de putrefacção que destroe em menos tempo partes relativamente mais resistentes do corpo.

Outra questão que por súa delicadeza reclama tambem a mais escrupulosa attenção da parte do observador e que vem por seu turno demonstrar a procedencia da theoria que venho de sustentar, consiste na possibilidade da gestação subsequentemente ao coito perineal. Neste sentido, ha poucos dias, recebi uma consulta concebida nos seguintes termos.A. diz-se gravida por ter B . tido relações com ella logo em seguida á cessação das regras. B diz que não houve tal: que, nessa occasião, apenas a sua verga tocou as partes genitaes externas de A. , tendo, comtudo havido ejaculação. Pergunta-se: nestas condições, isto é, tendo sido o contacto exterior, com ejaculação, é possivel a gravidez de A , sendo esta virgem?

Sim, respondo eu, é possivel a gravidez de A. , mesmo não tendo sido a sira hymen tocada. E' sabido que no congresso carnal desde que haja ejaculạção do semen nos orgãos genitaes externos da mulher, na vulva, os spermatozoides, cellulas fecundantes, tendo movimentos proprios e activos, mesmo depois da morte do homem, podem penetrar na vagina e fecundar a mulher cuja hymen ficou intacta. $\mathrm{E}$, se para affirmar-se a defloração, no seu sentido. 
medico-legal, fosse mistér a ruptura dessa membrana, ahi teriamos uma donzella gravida, em antagonismo á verdadeira doutrina. Por isso, em logar de defloração que no seu sentido anatomico, importa a laceração da hymen, se deveria empregar o vocabulo desvirginamento, que não só abrange esse, como todos os outros casos em que a membrana tendo sido atacada fendeu-se ou então cedeu sem lesar-se, como ainda o caso da consulta acima.

Ninguem dirá que A. seja uma virgem desde que está gravida. Sua virgindade não desappareceû̉ por um traumatismo sexual de fóra para dentro; mas desapparecerá pela violencia distensiva de dentro para fóra desde que, gravida, ella tenha de parir, quando romper-se a sua membrana, salvo casos rarissimamente excepcionaes, mas que parecem fidedignos e authenticos de um primeiro parto, mesmo a termo, deixar illesa a hymen, como citam alguns autores.

Não sei se as relações de A e B tiveranı logar uma ou mais vezes. Se por diversas vezes, ahi está o caso da fossa navicular vir demonstral-o em virtude de sua alteração, de fórma e concorrer para a segurança do estabelecimento do diagnostico.

Cumpre lembrar que o legislador, de accôrdo com a sciencia, teve em vista proteger a honra da mulher e não a integridade de uma membrana anatomica, cuja ausencia póde constituir um defeito congenito, como póde não romper-se ainda depois de protrahida vida conjugal, como até nas prostitutas.

A vista, pois, do exposto, concluo.

$$
\text { I. }^{\circ}
$$

O desvirginamento reclama para o seu diagnostico medico-legal um conjuncto de signaes e não um só : regra geral. 
De todos estes signaes o mais importante é a laceração da hymen quando devidamente discriminada das divisões congenitas desta membrana.

$$
3^{\circ}
$$

Casos ha, porém, em que o estado dessa membrana não subsidia o diagnostico.

$$
4^{\circ}
$$

Nestas condições excepcionaes, a fossa navicular, por si só, esclarece o diagnostico, donde sua maior importancia relativa.

S. Paulo, 22 de Março de r 907.

Dr. Amancio de Carvalho. 